\title{
Photothermal treatment of liver cancer with albumin-conjugated gold nanoparticles initiates Golgi Apparatus-ER dysfunction and caspase-3 apoptotic pathway activation by selective targeting of $\mathrm{Gp60}$ receptor [Corrigendum]
}

Mocan L, Matea C, Tabaran FA, et al. Int J Nanomedicine. 2015;10:5435-5445.

Page 5445, the Author contributions section shown below should have been included before the Disclosure section.

\section{Author contributions}

All authors made substantial contributions to conception and design, acquisition of data, or analysis and interpretation of data; took part in either drafting the article or revising it critically for important intellectual content; gave final approval of the version to be published; and agree to be accountable for all aspects of the work. All authors contributed equally to this paper.

\section{Publish your work in this journal}

The International Journal of Nanomedicine is an international, peerreviewed journal focusing on the application of nanotechnology in diagnostics, therapeutics, and drug delivery systems throughout the biomedical field. This journal is indexed on PubMed Central, MedLine, CAS, SciSearch ${ }^{\circledR}$, Current Contents ${ }^{\circledR} /$ Clinical Medicine,

\section{Dovepress}

Journal Citation Reports/Science Edition, EMBase, Scopus and the Elsevier Bibliographic databases. The manuscript management system is completely online and includes a very quick and fair peer-review system, which is all easy to use. Visit http://www.dovepress.com/ testimonials.php to read real quotes from published authors. 